\title{
Identification, Distribution, and Pathogenicity of Diatrypaceae and Botryosphaeriaceae Associated with Citrus Branch Canker in the Southern California Desert
}

Joey S. Mayorquin, Danny H. Wang, Mathias Twizeyimana, and Akif Eskalen, Department of Plant Pathology and Microbiology, University of California, Riverside 92521

\begin{abstract}
Mayorquin, J. S., Wang, D. H., Twizeyimana, M., and Eskalen, A. 2016. Identification, distribution, and pathogenicity of Diatrypaceae and Botryosphaeriaceae associated with citrus branch canker in the southern California desert. Plant Dis. 100:2402-2413.

Several members of the families Botryosphaeriaceae and Diatrypaceae are known as canker and dieback pathogens of a number of woody hosts. Because desert citrus production in California can occur in proximity to table grape production, it was suspected that fungi associated with grapevine cankers might also be associated with citrus branch canker and dieback decline. To determine the fungi associated with branch canker and dieback disease of citrus in the southern California desert regions, surveys were conducted from 2011 to 2013 in the major citrus-growing regions of Riverside, Imperial, and San Diego Counties. Cankered tissues were collected from branches showing symptoms typical of branch canker and dieback. Various fungal species were recovered from necrotic tissues and species were identified morphologically and by phylogenetic comparison of partial sequences of the internal transcribed spacer (ITS) region (ITS1-5.8S-ITS2), $\beta$-tubulin gene, and elongation factor $1-\alpha$ genes with those of other species in GenBank. Four fungi, including Neoscytalidium hyalinum, Eutypella citricola, E. microtheca, and an

unnamed Eutypella sp., were associated with branch canker. $N$. hyalinum was the most frequently recovered fungus from symptomatic tissues $(31 \%)$ followed by E. citricola $(10 \%)$, E. microtheca $(4 \%)$, and the Eutypella sp. (2\%). In pathogenicity tests, all fungi caused lesions when inoculated on 'Lisbon' lemon (citrus) branches. Lesions caused by the Eutypella sp. were significantly longer than those of the other Eutypella spp.; however, they did not differ significantly from those produced by $N$. hyalinum. The most-parsimonious unrooted trees based on the combined data of ITS and partial $\beta$-tubulin gene region sequences showed three distinct clades of Eutypella spp. (E. citricola, E. microtheca, and an unidentified Eutypella sp.). Similarly, ITS and partial translation elongation factor 1- $\alpha$ gene region sequences differentiated two species of Neoscytalidium, $N$. hyalinum and N. novaehollandiae. Identifying the diversity, distribution, and occurrence of these fungal pathogens is useful for the management of citrus branch canker and dieback disease in the desert citrus-growing regions of California
\end{abstract}

Citrus production in California is valued at over $\$ 1.9$ billion and California is ranked second in overall production value in the United States (Anonymous 2015). Citrus production in California extends from central to southern California, with orchards located in the desert areas of Coachella Valley (Riverside County), Imperial Valley (Imperial County), and Borrego Springs (San Diego County) primarily focused on lemon and grapefruit varieties. Over half of California's total grapefruit production and nearly one-fifth of the total lemon production occur in the desert regions of California (Anonymous 2009).

Canker and dieback diseases of woody hosts are common and continue to be extensively studied in both agricultural and nonagricultural fields. Many of these studies have shown the diversity of members of the families Botryosphaeriaceae or Diatrypaceae occurring on a number of agricultural commodities in California (almond, avocado, cherry, citrus, and grapevine) and worldwide (almond, apricot, and grapevine); in some cases, host overlap exists between these two families, further requiring a better understanding of the overall dieback disease complex throughout the world where this occurs (Adesemoye et al. 2014; Carter 1957; Gramaje et al. 2012; Inderbitzin et al. 2010; McDonald and Eskalen 2011; Munkvold and Marois 1994; Trouillas et al. 2010, 2011; Úrbez-Torres et al. 2006). The economic impact of these canker diseases on crop productivity has not

Current address of M. Twizeyimana: AgBiome, Inc., 104 T. W. Alexander Drive, Building 1, Research Triangle Park, NC 27709.

Corresponding author: A. Eskalen; E-mail: akif.eskalen@ucr.edu

Accepted for publication 7 July 2016.

http://dx.doi.org/10.1094/PDIS-03-16-0362-RE

(C) 2016 The American Phytopathological Society been enumerated for every crop host but it is suggested that the effect of these diseases could be financially substantial. In California, cordon and trunk canker diseases of grapevine account for the primary cause of plant mortality (Trouillas et al. 2010) and the economic losses are estimated to be up to $\$ 260$ million (Siebert 2001) per year. Of these diseases, Eutypa dieback caused by Eutypa lata (Diatrypaceae) is considered one of the most important canker diseases of grapevine in California and worldwide (Moller and Kasimatis 1978) and is also of economic importance in apricot (Carter 1957). Other members of the Diatrypaceae family are known to be associated with grapevine trunk diseases (Luque et al. 2012; Trouillas et al. 2010, 2011; Urbez-Torres et al. 2009, 2012); however, their individual impact on the overall economic loss from these diseases is not known. The economic loss resulting from branch canker pathogens of citrus in California has not been determined and it is likely that the significance of these pathogens on citrus both in California and worldwide is more appreciable than currently understood (Adesemoye et al. 2014).

Branch canker and dieback diseases of citrus have been reported since the early 1900s (Punithalingham 1980). Symptoms of these diseases generally include the presence of dead, sunken bark around dark-colored cankers, twig and branch dieback, and gummosis. Susceptibility to these diseases is influenced by wounding and a weakening of trees which can include frost damage, sunburn, and other abiotic factors (Calavan and Wallace 1954; Whiteside 1980). Various Botryosphaeriaceae species are known to cause branch canker and dieback in citrus, including Diplodia natalensis Pole-Evans, Dothiorella gregaria Sacc., and Hendersonula toruloidea Nattrass (Calavan and Wallace 1954; Punithalingham 1980; Whiteside 1980). The disease known as Hendersonula branch wilt, or simply Hendersonula, caused by the botryosphaeriaceous fungus Neoscytalidium hyalinum (C. K. Campb. \& J. L. Mulder) A. J. L. Phillips, M. Groenew. \& Crous (formerly H. toruloidea and $N$. dimidiatum) has been reported to be affecting desert citrus production in California 
(Calavan and Wallace 1954) and Israel (Oren et al. 2001). Symptoms include characteristic black spore masses underneath the bark, branch cankers, wilt, and dieback. Recently, 10 species in the Botryosphaeriaceae family have been identified associated with branch canker and dieback of citrus in California (Adesemoye et al. 2014). In addition, Eutypella microtheca and a Eutypella sp. were reported for the first time on 'Allen Eureka' lemon and 'Red Blush' grapefruit in Riverside and San Diego Counties, respectively, in 2011 (Adesemoye and Eskalen, 2011).

A number of Eutypella spp. has been previously recorded from citrus species, including Citrus aurantium, C. limon, C. maxima, C. paradisi, and a Citrus sp. in Argentina, Brazil, Philippines, Cote d'Ivoire, and Australia (Hanlin 1992; Rappaz 1987; Reinking 1918; Resplandy et al. 1954; Trouillas et al. 2011). E. citricola Speg. was reported on dead twigs of a Citrus sp. in Florida (Anonymous 1960). However, there is no record of this genus occurring on citrus in North America other than the study by Adesemoye and Eskalen (2011). Although it appears that the genus Eutypella has been implicated in the dieback of citrus in various regions worldwide, to our knowledge, it has not been formally investigated as a potential pathogen of citrus, at least in California (Anonymous 1960; Hanlin 1992; Rappaz 1987; Reinking 1918; Resplandy et al. 1954; Trouillas et al. 2011). Several species of Eutypella have been reported from other woody hosts in California, including grapevine (Trouillas et al. 2010) and nonagricultural trees and shrubs such as California buckeye, baccharises, white alder, and box elder (French 1989, Rappaz 1987; Trouillas et al. 2010), and those associated with grapevine in California were shown to produce lesions when artificially inoculated on grapevine, confirming these species as pathogens on grapevine. Eutypella spp. made up over $60 \%$ of all fungi isolated from grapevine cankers in the Coachella Valley (Trouillas et al. 2010), a region which is home to table grape and citrus production, both of which can occur in close proximity to each other. Hence, it is likely that citrus in the Coachella Valley are susceptible to infection by Eutypella spp.

The objectives of this study were to (i) characterize the symptomatology of citrus branch canker in the southern California desert regions, (ii) identify fungi associated with citrus branch canker based on morphological traits and molecular phylogenetic analysis, (iii) assess the pathogenicity of recovered fungi, and (iv) determine the distribution of fungi associated with this disease among counties.

\section{Materials and Methods}

Field survey and isolation. Surveys were conducted in nine commercial citrus orchards within the desert production region of California, including Coachella Valley (four orchards in Riverside County), Imperial Valley (four in Imperial County), and Borrego Springs (one in San Diego County) between summer 2011 and spring 2013 and in summer 2015. Approximately 30 trees were sampled from each orchard and cankered tissues from a single branch were collected from each tree showing symptoms typical of branch canker and dieback, including but not limited to depressed bark on cankered branches, bark cracking and splitting, gumming, and a layer of black sooty spores directly under the bark. When possible, citrus trees growing in close proximity to grapevine were sampled. Surrounding hardwood trees (tamarix; Tamarix ramosissima) in the vicinity of citrus groves were examined for symptoms of branch canker and dieback and samples were taken. In total, 273 samples were collected.

Samples were rinsed with distilled water to remove organic debris, dipped in $95 \%$ ethanol, and flamed to burn off excess alcohol. The bark was removed to expose the necrotic and healthy tissues and small pieces from the margin of necrotic lesions were placed onto the surface of potato dextrose agar (PDA; Difco Laboratories) plates amended with $0.0 \%$ tetracycline hydrochloride (Fisher Scientific) (PDA-tet). Isolation plates were incubated in the dark at room temperature for 3 to 5 days. Pure cultures from emerging fungi were obtained by transferring hyphal tips from the colony margin to water agar; single hypha were excised with the aid of a stereomicroscope and subsequently transferred to acidified PDA plates. Fungal isolates were stored as mycelial plugs in sterile water $\left(4^{\circ} \mathrm{C}\right)$ and $30 \%$ glycerol $\left(-80^{\circ} \mathrm{C}\right)$.

Morphological identification. Fungal isolates were identified initially to genus based on gross colony morphology (colony color, colony growth pattern, and rate of growth) and those belonging to the families Diatrypaceae and Botryosphaeriaceae were further studied using published descriptions (Crous et al. 2006; Phillips et al. 2013; Slippers et al. 2013; Trouillas et al. 2010). To induce conidial production (van Niekerk et al. 2004), isolates were grown on oatmeal agar (OA; oat flakes at $30 \mathrm{~g} /$ liter) and incubated at room temperature under continuous fluorescent light until fruiting structures (pycnidia) developed. In some cases, autoclaved pine needles or citrus wood chips were added to the surface of agar media to enhance fruiting body production. Oozing conidial masses were collected with a sterile inoculating loop and mounted on a microscope slide in a drop of lactoglycerol. The length (arc length for filiform conidia) and width of 30 conidia were measured for each isolate on a compound microscope using SPOT Imaging software (Diagnostic Instruments Inc.). The mean, standard deviation, minimum, mode, and maximum conidial lengths and widths were calculated for each isolate. To determine the effect of temperature on fungal radial growth, two isolates for each fungal species were grown on PDA and incubated at eight different temperatures $\left(5,10,15,20,25,30,35\right.$, and $\left.40^{\circ} \mathrm{C}\right)$ for 4 days. Colony diameter was measured every day for 4 days and this experiment was repeated once. Average daily growth was calculated by computing the average growth for fungal isolates at 2 and 3 days of growth at the indicated temperatures.

DNA isolation, amplification, and phylogenetic analysis. Genomic DNA for each isolate was extracted from pure cultures following the method of Cenis, with slight modifications (Cenis 1992). In brief, mycelia were scraped from agar plates and placed into $2.0-\mathrm{ml}$ conical vials containing extraction buffer $(200 \mathrm{mM}$ Tris $\mathrm{HCl}[\mathrm{pH} 8.5]$, $250 \mathrm{mM} \mathrm{NaCl}, 25 \mathrm{mM}$ EDTA, and $0.5 \%$ sodium dodecyl sulfate) and glass beads. Tubes were bead bashed using a FastPrep-24 machine (MP Biomedicals Inc.) at $4 \mathrm{M} / \mathrm{s}$ for $30 \mathrm{~s}$. Oligonucleotide primers internal transcribed spacer (ITS) 4 and ITS5 (White et al. 1990) were used to amplify the ITS1-5.8S-ITS2 region of the ribosomal DNA, primers Bt2a and Bt2b (White et al. 1990) were used to amplify a partial region of the nuclear $\beta$-tubulin gene, and primers EF1F and EF2R (Jacobs et al. 2004) were used to amplify a portion of the translation elongation factor (EF) 1- $\alpha$ gene. Polymerase chain reaction (PCR) was carried out as previously described (Slippers et al. 2004). Reaction mixtures consisted of $1 \times$ reaction buffer, $0.2 \mathrm{mM}$ dNTP, $0.2 \mu \mathrm{M}$ forward and reverse primers, $2.5 \mathrm{U}$ of standard Taq polymerase (New England Biolabs), and template DNA ranging from 50 to $100 \mathrm{ng} / \mu \mathrm{l}$. Cycling conditions were as follows: an initial preheat at $95^{\circ} \mathrm{C}$ for $2 \mathrm{~min}$; followed by 40 cycles of denaturation at $95^{\circ} \mathrm{C}$ for $15 \mathrm{~s}$, annealing at $55^{\circ} \mathrm{C}\left(63^{\circ} \mathrm{C}\right.$ for EF1F/EF2R) for $30 \mathrm{~s}$, and extension at $72^{\circ} \mathrm{C}$ for $2 \mathrm{~min}$; followed by a final extension at $72^{\circ} \mathrm{C}$ for $5 \mathrm{~min}$. PCR products were verified by gel electrophoresis in $1 \times$ Tris-borate-EDTA buffer and photographed under UV light after staining with SYBR Green (Invitrogen). PCR products were purified using ExoSAP-IT (Affymetrix) and sequenced in both directions using the primers mentioned above at the Institute for Integrative Genome Biology of the University of California, Riverside.

Sequences were edited using Sequencher 4.6 (Gene Codes Corp.) and local alignments were done using Clustal X (Thompson et al. 1997). Phylogenetic analysis was performed with MEGA6 (Tamura et al. 2013) and sequences in the present study (Table 1) were compared with known sequences in GenBank (Table 2). Analyses were run separately for ITS, $\beta$-tubulin, and EF1- $\alpha$ datasets, and ITS and $\beta$-tubulin and ITS and EF1- $\alpha$ datasets were combined and analyzed for the Diatrypaceae and Botryosphaeriaceae families, respectively. Maximum-parsimony analysis was performed for each dataset using the Subtree-Pruning-Regrafting search method, with gaps and missing data treated as a complete deletion. Bootstrap values were obtained from 1,000 bootstrap replications and tree length, consistency index (CI), retention index (RI), rescaled consistency index (RCI), and homoplasmy index were recorded. 
Pathogenicity tests and effect of temperature on fungal colonization. Pathogenicity tests were conducted on 3-year-old 'Lisbon' lemon (C. limon) grafted on C-35 citrange rootstock maintained in a greenhouse (average temperature range of 21 to $32^{\circ} \mathrm{C}$ ) from December 2013 to August 2014. To assess pathogenicity, plants were stem wound-inoculated on the scion (approximately $1 \mathrm{~cm}$ in diameter) with a 4-mm-diameter cork borer to remove bark; there was one inoculation site per scion shoot inoculated. Then, an agar plug was taken from the colony margin of a 1-week-old fungal culture for each isolate (Table 1) and placed mycelia side down on the wound. Wounds were covered with petroleum jelly and wrapped with Parafilm. Control shoots were inoculated with sterile agar plugs. Inoculated plants and controls were arranged in a randomized complete block design with four replications and the experiment was repeated once. Shoots were destructively sampled after 8 months to measure internal vascular necrosis (lesions). Necrotic tissues developing outside the area of inoculation were cultured on PDA-tet and fungal isolates obtained from reisolation were identified based on their morphology (colony shape, color, and growth rate) and by sequencing the ITS region as described earlier to fulfill Koch's postulates.

To assess the effect of temperature on fungal colonization, healthy twigs from Lisbon lemon trees were collected and transported back to the laboratory at the University of California, Riverside. Twigs were rinsed in distilled water to remove surface debris and then soaked in a solution of $10 \%$ household bleach for $10 \mathrm{~min}$ to surface disinfect. Leaves were removed and twigs were cut into segments approximately $12 \mathrm{~cm}$ long. The ends of these segments were dipped into paraffin wax to prevent desiccation. A 4-mm cork borer was used to make a wound by removing bark and then a fungal plug from a 1 -week-old culture (Table 1) was placed in the wound mycelial side down. Control twigs were inoculated with sterile agar plugs. Wounds were covered with petroleum jelly and wrapped with Parafilm. The experiment design was a two-level factorial design with temperature and isolate as factors. Inoculated twigs and controls were placed in containers containing a moistened paper towel to provide humidity and incubated at 25 or $32^{\circ} \mathrm{C}$ in microbiological incubators for 10 days. Each temperature and isolate combination had five replications and the experiment was repeated once. After incubation, segments were destructively sampled by removing the bark and measuring internal vascular necrosis. Necrotic tissue from the margin of lesions was taken and placed onto PDA-tet to confirm fungal presence. Fungal colonies were identified based on gross colony morphology.

Statistical analysis. Internal lesion lengths from the pathogenicity test were analyzed using JMP Pro 11 (SAS Institute). One-way analysis of variance was used to compare lesion length means. All pairs of means were compared using Tukey's honestly significant difference

Table 1. Representative isolates of Neoscytalidium hyalinum and Eutypella spp. recovered from citrus branch cankers from desert citrus in southern California

\begin{tabular}{|c|c|c|c|c|c|c|}
\hline \multirow[b]{2}{*}{ Species } & \multirow[b]{2}{*}{ Isolate } & \multirow[b]{2}{*}{ County } & \multirow[b]{2}{*}{ Host } & \multirow[b]{2}{*}{ Variety } & \multicolumn{2}{|c|}{ GenBank number } \\
\hline & & & & & ITS $^{\mathbf{a}}$ & EF1- $\alpha$ or $\beta$-tubulin ${ }^{b}$ \\
\hline Neoscytalidium hyalinum & $\mathrm{UCRDC} 8^{\mathrm{c}}$ & Imperial & Citrus paradisi & Rio Red & KF620362 & KF620398 \\
\hline N. hyalinum & UCRDC29 & Imperial & C. paradisi & Rio Red & KF620363 & KF620399 \\
\hline$N$. hyalinum & UCRDC59 & Riverside & C. paradisi & Pink & KF620364 & KF620400 \\
\hline N. hyalinum & UCRDC65 & Riverside & C. paradisi & Pink & KF620365 & KF620401 \\
\hline N. hyalinum & UCRDC132 & Riverside & C. limon & Allen Eureka & KF620366 & KF620402 \\
\hline N. hyalinum & UCRDC170 & Imperial & C. paradisi & Ruby Red & KF620367 & KF620403 \\
\hline$N$. hyalinum & UCRDC176 & Imperial & C. paradisi & Rio Red & KF620368 & KF620404 \\
\hline$N$. hyalinum & UCRDC280 & San Diego & C. limon & Lisbon & KF620369 & KF620405 \\
\hline N. hyalinum & UCRDC284 & San Diego & C. limon & Lisbon & KF620370 & KF620406 \\
\hline Eutypella citricola & UCRDC06 & Imperial & C. paradisi & Rio Red & KF620371 & KF620407 \\
\hline E. citricola & UCRDC83 & Riverside & C. limon & Allen Eureka & KF620372 & KF620408 \\
\hline E. citricola & UCRDC88 & Riverside & C. limon & Allen Eureka & KF620373 & KF620409 \\
\hline E. citricola & UCRDC90 & Riverside & C. limon & Allen Eureka & KF620374 & KF620410 \\
\hline E. citricola & UCRDC $91^{c}$ & Imperial & C. paradisi & Rio Red & KF620375 & KF620411 \\
\hline E. citricola & UCRDC112 & Imperial & C. paradisi & Rio Red & KF620376 & KF620412 \\
\hline E. citricola & UCRDC113 & Imperial & C. paradisi & Rio Red & KF620377 & KF620413 \\
\hline E. citricola & $\mathrm{UCRDC} 117^{\mathrm{c}}$ & Imperial & C. paradisi & Rio Red & KF620378 & KF620414 \\
\hline E. citricola & UCRDC186 & Imperial & C. paradisi & Ruby Red & KF620379 & KF620415 \\
\hline E. citricola & UCRDC272 & San Diego & C. limon & Lisbon & KF620380 & KF620416 \\
\hline E. citricola & UCRDC291 & San Diego & Tamarix sp. & $\ldots$ & KF620381 & KF620417 \\
\hline E. citricola & UCRDC293 & San Diego & C. limon & Lisbon & KF620382 & KF620418 \\
\hline E. citricola & UCRDC333 & Riverside & C. limon & Allen Eureka & KF620383 & KF620419 \\
\hline Eutypella microtheca & $\mathrm{UCRDC}^{\mathrm{C}} \mathrm{9}^{\mathrm{c}}$ & Imperial & C. paradisi & Rio Red & KF620384 & KF620420 \\
\hline E. microtheca & $\mathrm{UCRDC} 37^{\mathrm{c}}$ & Imperial & C. paradisi & Rio Red & KF620385 & KF620421 \\
\hline E. microtheca & UCRDC67 & Riverside & C. paradisi & Pink & KF620386 & KF620422 \\
\hline E. microtheca & UCRDC103 & Riverside & C. paradisi & Pink & KF620387 & KF620423 \\
\hline E. microtheca & UCRDC106 & Riverside & C. paradisi & Pink & KF620388 & KF620424 \\
\hline E. microtheca & UCRDC148 & Imperial & C. limon & Lisbon & KF620389 & KF620425 \\
\hline E. microtheca & UCRDC325 & Riverside & C. limon & Allen Eureka & KF620390 & KF620426 \\
\hline Eutypella sp. & UCRDC142 & Riverside & C. limon & Allen Eureka & KF620391 & KF620427 \\
\hline Eutypella sp. & UCRDC143 & Riverside & C. limon & Allen Eureka & KF620392 & KF620428 \\
\hline Eutypella sp. & UCRDC $210^{c}$ & Imperial & C. paradisi & Ruby Red & KF620393 & KF620429 \\
\hline Eutypella sp. & UCRDC211 & Imperial & C. paradisi & Ruby Red & KF620394 & KF620430 \\
\hline Eutypella sp. & UCRDC $276^{\mathrm{c}}$ & San Diego & C. limon & Lisbon & KF620395 & KF620431 \\
\hline Eutypella sp. & UCRDC287 & San Diego & Tamarix sp. & $\ldots$ & KF620396 & KF620432 \\
\hline Eutypella sp. & UCRDC335 & Riverside & C. limon & Allen Eureka & KF620397 & KF620433 \\
\hline
\end{tabular}

a ITS = internal transcribed spacer region.

${ }^{\mathrm{b}} \mathrm{EF} 1-\alpha=$ translation elongation factor $1-\alpha$. Accession numbers given for $N$. hyalinum correspond to the EF1- $\alpha$ gene and accession numbers given for Eutypella spp. correspond to the $\beta$-tubulin gene.

${ }^{c}$ Isolates used in pathogenicity test and the effect of temperature experiment. 
(HSD), where $\alpha=0.05$. Data from the independent trials was checked for homogeneity error of variance and no heterogeneity was detected; thus, data from each independent trial were combined. To assess the effect of temperature on fungal colonization, lesion lengths were analyzed by an independent-samples $t$ test with confidence level $\alpha=0.05$ using JMP Pro 11. To construct fungal radial growth curves, daily growth was plotted against temperature and fit to a Weibull five-parameter regression curve using the probability

Table 2. Sequences and their description of the fungal species obtained from GenBank used in the phylogenetic study

\begin{tabular}{|c|c|c|c|c|c|}
\hline \multirow[b]{2}{*}{ Isolate } & \multirow[b]{2}{*}{ Species } & \multirow[b]{2}{*}{ Host } & \multirow[b]{2}{*}{ Origin } & \multicolumn{2}{|c|}{ GenBank number } \\
\hline & & & & ITS $^{\mathbf{a}}$ & EF1- $\alpha$ or $\beta$-tubulin $b$ \\
\hline HVGRF01 & Eutypella citricola & Citrus paradisi & Australia & HQ692589 & HQ692521 \\
\hline HVVIT07c & E. citricola & Vitis vinifera & Australia & HQ692579 & HQ692512 \\
\hline WA06FH & E. citricola & $V$. vinifera & Australia & HQ692588 & HQ692518 \\
\hline UCD2342Co & E. citricola & V. vinifera & California & GQ293968 & GQ294022 \\
\hline UCD2349Co & E. citricola & V. vinifera & California & GQ293969 & GQ294021 \\
\hline MSUELM13 & E. vitis & $V$. vinifera & United States & DQ006943 & DQ006999 \\
\hline UCD2428TX & E. vitis & $V$. vinifera & United States & FJ790851 & GU294726 \\
\hline HVFIG02 ${ }^{\mathrm{c}}$ & E. cryptovalsoidea & Ficus carica & Australia & HQ692573 & HQ692524 \\
\hline HVFIG05 & E. cryptovalsoidea & F. carica & Australia & HQ692574 & HQ692525 \\
\hline $\mathrm{HVGRF02}^{\mathrm{c}}$ & E. microtheca & C. paradisi & Australia & HQ692569 & HQ692533 \\
\hline UCD2Co & E. microtheca & $V$. vinifera & California & GQ293958 & GQ294018 \\
\hline UCD3Co & E. microtheca & V. vinifera & California & GQ293957 & GQ294019 \\
\hline YC17 & E. microtheca & V. vinifera & Australia & HQ692562 & HQ692537 \\
\hline YC24 & E. microtheca & V. vinifera & Australia & HQ692565 & HQ692530 \\
\hline UCD713SJ & Eutypella sp. & V. vinifera & California & GQ293955 & GQ294016 \\
\hline BAFC3321 & Peroneutypa scoparia & $\mathrm{N} / \mathrm{A}^{\mathrm{d}}$ & Argentina & EU702431 & EU728698 \\
\hline BAFC3322 & P. scoparia & N/A & Argentina & EU702432 & EU728699 \\
\hline DFMAL100 & P. scoparia & Robinia pseudoacacia & France & GQ293962 & GQ294029 \\
\hline UCD2334Co & Eutypella sp. & V. vinifera & California & GQ293963 & GQ294027 \\
\hline UCD2335Co & Eutypella sp. & V. vinifera & California & GQ293964 & GQ294028 \\
\hline EP18 & Eutypa lata & V. vinifera & Australia & HQ692611 & HQ692501 \\
\hline RGA01 & E. lata & Fraxinus angustifolia & Australia & HQ692614 & HQ692497 \\
\hline ADSC300 & E. lata & Schinus molle & Australia & HQ692610 & HQ692493 \\
\hline HVGRF03 $^{c}$ & Diatrypella vulgaris & C. paradisi & Australia & HQ692590 & HQ692502 \\
\hline HVPT01 & D. vulgaris & S. molle & Australia & HQ692594 & HQ692506 \\
\hline RGA02 & E. leptoplaca & F. angustifolia & Australia & HQ692602 & HQ692483 \\
\hline TUQU01 & E. leptoplaca & Quercus sp. & Australia & HQ692598 & HQ692491 \\
\hline CBS251.49 & Neoscytalidium hyalinum & Juglans regia & United States & KF531819 & KF531797 \\
\hline CBS145.78c & N. hyalinum & Homo sapiens & United Kingdom & KF531816 & KF531795 \\
\hline WAC12693 & N. hyalinum & Mangifera indica & Australia & EF585538 & EF585576 \\
\hline WAC12690 & N. hyalinum & M. indica & Australia & EF585537 & EF585577 \\
\hline CBS499.66 & N. hyalinum & M. indica & Mali & KF531820 & EU144063 \\
\hline CBS122610 & N. novaehollandiae & Acacia synchronicia & Australia & EF585536 & EF585578 \\
\hline WAC12691 & N. novaehollandiae & M. indica & Australia & EF585543 & EF585574 \\
\hline WAC 13303 & N. novaehollandiae & M. indica & Australia & GU172398 & GU172430 \\
\hline CBS122070 & N. novaehollandiae & Grevillea agrifolia & Australia & EF585539 & EF585579 \\
\hline WAC13304 & N. novaehollandiae & M. indica & Australia & GU172399 & GU172431 \\
\hline WAC12688 & N. novaehollandiae & M. indica & Australia & EF585542 & EF585575 \\
\hline CBS122072 & N. novaehollandiae & Adansonia gibbosa & Australia & EF585535 & EF585581 \\
\hline WAC13273 & N. novaehollandiae & M. indica & Australia & GU172397 & GU172429 \\
\hline CBS122071 ${ }^{\mathrm{c}}$ & N. novaehollandiae & Crotalaria medicaginea & Australia & EF585540 & EF585580 \\
\hline WAC13275 & N. novaehollandiae & M. indica & Australia & GU172400 & GU172432 \\
\hline MFLUCC11-0425c & Cophinforma eucalypti & Eucalyptus sp. & Thailand & JX646800 & JX646865 \\
\hline MFLUCC11-0655 & C. eucalypti & Eucalyptus sp. & Thailand & JX646801 & JX646866 \\
\hline CMW22674 & $C$ atrovirens & Pterocarpus angolensis & South Africa & FJ888473 & FJ888456 \\
\hline MFLUCC10-0051 & Botryosphaeria agaves & Agave sp. & Thailand & JX646790 & JX464855 \\
\hline MFLUCC $11-0125^{\mathrm{c}}$ & B. agaves & Agave sp. & Thailand & JX646791 & JX646856 \\
\hline ATCC22927 & $B$ corticis & Vaccinium sp. & United States & DQ299247 & EF614931 \\
\hline CBS119047c & B. corticis & V. corymbosum & United States & DQ299245 & EU017539 \\
\hline MFLUCC10-0098c & B fusispora & Entada sp. & Thailand & JX646789 & JX646854 \\
\hline CBS116741 & B. dothidea & Olea europaea & Greece & AY640254 & AY640257 \\
\hline CMW8000 & B. dothidea & Prunus sp. & Switzerland & AY236949 & AY236898 \\
\hline CBS110302 & B. dothidea & Vitis sp. & Portugal & AY259092 & AY573218 \\
\hline CBS162.25 & Macrophomina phaseolina & Eucalyptus sp. & N/A & KF531826 & KF531803 \\
\hline CBS447.68 & Phyllosticta foliorum & Taxus baccata & Netherlands & FJ824768 & FJ824773 \\
\hline CBS22733 & M. phaseolina & Zea mays & N/A & KF531825 & KF531804 \\
\hline
\end{tabular}

${ }^{a}$ ITS $=$ internal transcribed spacer region.

${ }^{\mathrm{b}} \mathrm{EF} 1-\alpha=$ translation elongation factor $1-\alpha$. Accession numbers given for the Botryosphaeriaceae correspond to the EF1- $\alpha$ gene and accession numbers given for Eutypella spp. correspond to the $\beta$-tubulin gene.

${ }^{\mathrm{c}}$ Denotes type-specimen.

${ }^{\mathrm{d}} \mathrm{N} / \mathrm{A}=$ not available. 
density function (Miller et al. 2003) in SigmaPlot (version 11; Systat Software Inc.).

\section{Results}

Field survey, fungal recovery, and distribution. Disease was observed on lemon and grapefruit trees ranging in age from 20 to 40 years old on the following varieties: Lisbon and Allen Eureka lemon (C. limon) and 'Rio Red', 'Ruby Red', and 'Pink' grapefruit (C. paradisi). Disease expression appeared to be more severe in C. paradisi cultivars than on C. limon cultivars. Tamarisk (Tamarix spp.) trees that were commonly observed lining citrus groves in San Diego County also displayed symptoms of branch canker and dieback.

Symptoms of branch canker on citrus in the desert regions were observed primarily on twigs and scaffold branches. On severely declining trees, lesions could be seen extending into the trunk. Diseased branches showed typical symptoms of depressed bark covering cankered areas; necrotic tissues ranging from dark, chocolate brown to nearly black and in some cases a salmon-colored zone at the margin of necrotic tissue were observed. Symptoms also included cracking or peeling of the bark, often associated with gumming. A layer of black fungal spores was observed directly underneath the bark, indicative of infection by $N$. hyalinum. In most cases, there was a dieback of the affected limb. Examination of fallen, decaying branches on orchard floors revealed numerous fruiting bodies resembling those of diatrypaceous fungi.

Both Neoscytalidium and Eutypella spp. were detected in all three counties sampled (Fig. 1A and B). At least two species of Eutypella were detected in each county. The frequency of Eutypella spp. recovered between counties varied but E. citricola was the most frequently recovered (Fig. 1B).

$N$. hyalinum was the most frequently isolated in Riverside and Imperial Counties (Table 3). In Riverside County, N. hyalinum and Eutypella spp. were recovered from 38 and 14\%, respectively, of necrotic tissues collected from branches. In Imperial County, N. hyalinum and Eutypella spp. were recovered from 27 and $16 \%$, respectively, of necrotic tissues collected from branches. N. hyalinum and Eutypella spp. were recovered from 10 and 27\%, respectively, of necrotic tissues collected from branches in San Diego. Both $N$. hyalinum and Eutypella spp. were isolated from necrotic tissues on the same branch at almost $3 \%$ of the total branches collected.

In Riverside County, 55\% of Eutypella isolates were identified as E. citricola, $30 \%$ as E. microtheca Trouillas, W. M. Pitt \& Gubler, and $15 \%$ as a Eutypella sp. (Table 3). In Imperial County, $56 \%$ of isolates were identified as E. citricola, $31 \%$ as E. microtheca, and $13 \%$ as a Eutypella sp. In San Diego County, $75 \%$ of isolates were identified as E. citricola and $25 \%$ as a Eutypella sp. E. microtheca was never recovered from San Diego County. Eutypella spp. were recovered from necrotic tissues collected from branches of tamarisk (Table 1).

Morphological identification. Three groups of Eutypella spp. were distinguished based on colony and conidial morphology (Table 4) and classified according to the system used by Trouillas et al. (2010). The most frequent group found associated with branch cankers in this area consisted of white colonies with moderate aerial mycelia, later developing spots of melanized hyphae. Pycnidia of these isolates produced orange-colored chirri of filiform conidia with a mean length and width of $14.8 \pm 1.6$ by $1.1 \pm 0.1 \mu \mathrm{m}$. Based on descriptions from isolates of grapevine, these isolates were morphologically similar to Eutypella sp. group 2 (Trouillas et al. 2010). The second group of Eutypella was characterized by colonies with abundant, white aerial mycelia that develop tufts of mycelium with age. These cultures were unique in the production of a pink pigment in culture on both PDA and OA. Pycnidia of these isolates exuded orange chirri of filiform conidia which were strongly curved, with a mean length and width of $14.1 \pm 2.4$ by $1.2 \pm 0.2 \mu \mathrm{m}$. These isolates were morphologically similar to the description of Eutypella sp. group 3 (Trouillas et al. 2010). Colonies from the third group of Eutypella were white, producing moderate aerial mycelia over time that developed a greenish, black center. Pycnidia exuded white conidial masses with filiform conidia, with a mean length and width of
$20.2 \pm 2.0$ by $1.3 \pm 0.3 \mu \mathrm{m}$. These isolates were morphologically similar to Eutypella sp. group 1 (Trouillas et al. 2010).

Only one group of Neoscytalidium sp. was identified based on colony and conidial morphology. This group consisted of colonies with mycelia initially light in color, developing dark olivaceous to black with age. Disarticulating hyphae were observed, forming 0 to 2 septate spores. Conidia from these isolates were initially hyaline and aseptate, later forming two septate brown spores, with a characteristic darker central cell. These isolates were morphologically similar to $N$. hyalinum (Phillips et al. 2013). Other fungal genera isolated at low frequencies from branch cankers included Aspergillus, Alternaria, Coniophora, Fusarium, Hypoxylon, and Spencermartinsia.

Results from the radial growth experiment revealed that all fungi could grow between 15 and $35^{\circ} \mathrm{C}$ (Fig. 2). N. hyalinum and E. microtheca were capable of growth at $40^{\circ} \mathrm{C}$; however, E. microtheca isolates grew very little $(<3 \mathrm{~mm})$ by the end of 3 days. Optimal temperatures for $N$. hyalinum, E. microtheca, and E. citricola occur between 30 and $35^{\circ} \mathrm{C}$ whereas the optimum temperature range for the Eutypella sp. is close to $30^{\circ} \mathrm{C}$.

Phylogenetic analyses. Phylogenetic analysis of individual loci produced similar tree topology and, thus, data sets for the ITS and $\beta$-tubulin (for the family Diatrypaceae) and ITS and EF1- $\alpha$ (for the family Botryosphaeriaceae) genes were combined and analyzed. The ITS tree topology for the family Diatrypaceae indicated that the Eutypella sp. was indistinguishable from Peroneutypa scoparia (Schwein.) Carmarán \& A. I. Romero; however, individual analysis of the $\beta$-tubulin dataset revealed the Eutypella sp. to be distinct from $P$. scoparia (not shown). The combined dataset for the family Diatrypaceae consisted of 975 nucleotides, with 328 nucleotides being parsimony informative, and maximum-parsimony analysis returned 10 most-parsimonious trees with the following scores: $\mathrm{CI}=0.73, \mathrm{RI}=$ 0.95 , and $\mathrm{RCI}=0.70$. The combined data set for the family Botryosphaeriaceae consisted of 796 nucleotides, of which 185 nucleotides were parsimony informative. Analysis of the combined dataset returned six most-parsimonious trees with the following scores: $\mathrm{CI}=0.85, \mathrm{RI}=$ 0.93 , and $\mathrm{RCI}=0.80$.

The Eutypella spp. from this study belonged to three distinct clades based on the combined data set (Fig. 3). The first clade (96\% bootstrap support) corresponds to E. citricola (Eutypella sp. group 1) (Trouillas et al. 2010). The second Eutypella clade (99\% bootstrap support) corresponds to E. microtheca Trouillas, W. M. Pitt \& Gubler (Eutypella sp. group 2) (Trouillas et al. 2010). The third clade (99\% bootstrap support) corresponds to an unidentified Eutypella sp. (Eutypella sp. group 3) (Trouillas et al. 2010). This species is most closely related to $P$. scoparia; however, isolates from this study form a subclade (69\% bootstrap support) that is distinct from P. scoparia (93\% bootstrap support).

For Neoscytalidium spp., one major clade (99\% bootstrap support) was formed from the combined dataset (Fig. 4). The first subclade ( $83 \%$ bootstrap support) corresponds to $N$. hyalinum, which includes isolates obtained from citrus in this study and other vouchered specimens from walnut, mango, and human; and the second subclade ( $95 \%$ bootstrap support) corresponds to $N$. novaehollandiae, which includes vouchered specimens from acacia, mango, blue grevillea, boab, and rattlepod in Australia.

Pathogenicity tests and effect of temperature on fungal colonization. At 2 to 4 weeks after fungal inoculation, gum production originating from the point of inoculation was present in shoots inoculated with fungi but was not present in control shoots. Bark splitting at the site of inoculation was frequently observed on shoots inoculated with $N$. hyalinum but less common on shoots inoculated with species of Eutypella; No bark splitting was observed at the point of inoculation on control shoots. All fungi tested were capable of causing lesions when inoculated on citrus branches (Fig. 5). Lesions from pathogen-inoculated shoots were light to dark brown in color and extended acro- and basipetally from the point of inoculation. Lesions were not observed on control branches. No significant differences in lesion lengths were observed between isolates of the same species; however, significant differences in lesion lengths were observed between different fungal species $(P<0.05)$. 
Lesions produced by the Eutypella sp. were significantly larger $(P<$ 0.05 ) than those of E. citricola and E. microtheca.; however, they did not differ significantly from those produced by $N$. hyalinum. Lesions produced by $N$. hyalinum were significantly larger $(P<0.05)$ than those produced by $E$. microtheca and E. citricola. Lesions produced by $E$. microtheca and $E$. citricola did not differ significantly from each other. All isolates were reisolated from inoculated branches and confirmed morphologically as identical to the isolates used in inoculations using the colony characteristics described earlier. Representative isolates were chosen for further characterization by sequencing of the ITS region as described earlier. Fungal recovery ranged from 75 to $100 \%$ for all isolates.

Significant differences $(P<0.05)$ in lesion length were observed among fungal species and between temperatures (Fig. 6).
For $N$. hyalinum, a significant difference $(P<0.001)$ was observed in lesion lengths between shoots incubated at 25 and $32^{\circ} \mathrm{C}$. Average lesion length at $25^{\circ} \mathrm{C}$ was $23.3 \mathrm{~mm}$ whereas the average lesion length at $32^{\circ} \mathrm{C}$ was $94.4 \mathrm{~mm}$. For isolates of E. microtheca, a significant difference $(P<0.01$ for isolate DC09 and $P<$ 0.05 for isolate DC37) was observed in lesion lengths when shoots incubated at $32^{\circ} \mathrm{C}$ were compared with those incubated at $25^{\circ} \mathrm{C}$. Larger lesions were produced on segments incubated at $32^{\circ} \mathrm{C}$ then when incubated at $25^{\circ} \mathrm{C}$. For E. citricola, a significant difference in lesion length $(P<0.05)$ was observed in only one isolate (DC91). This isolate showed a significant decrease in lesion length from segments incubated at $32^{\circ} \mathrm{C}$ in comparison with those segments incubated at $25^{\circ} \mathrm{C}$. The other isolate of $E$. citricola showed no significant differences in lesion length at either temperature. For isolates
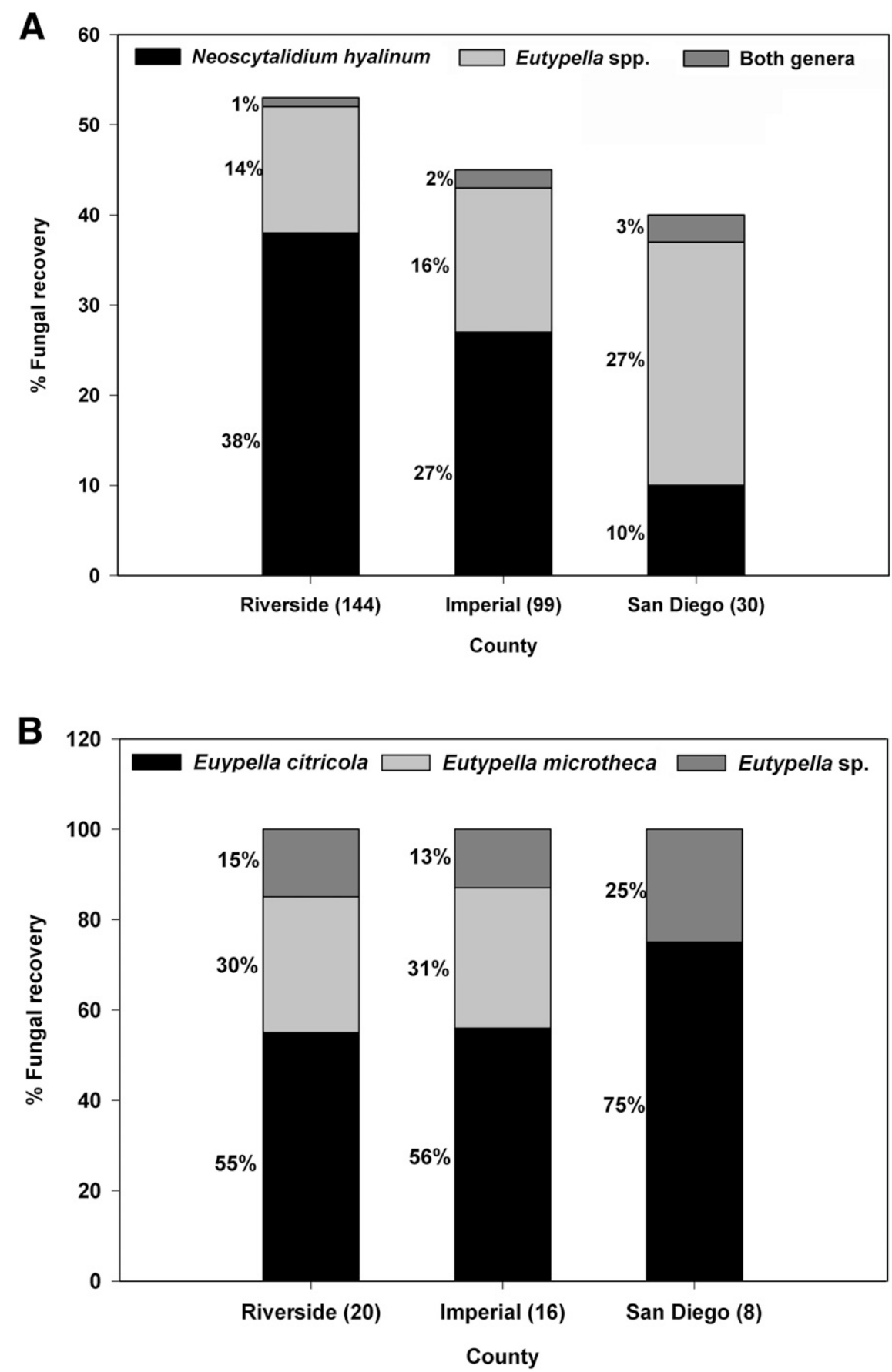

Fig. 1. Fungal recovery (\%) of A, Neoscytalidium hyalinum and Eutypella spp. and B, Eutypella spp. by county. Numbers in parentheses following county names indicate the number of symptomatic branches collected in that county. Percentages were rounded to the nearest whole number. 
of the Eutypella sp., no significant difference was observed in lesion lengths at either temperature. Fungal recovery from these segments ranged from 95 to $100 \%$.

\section{Discussion}

This study is the first comprehensive assessment of the distribution, identification, and pathogenicity of fungal species associated with citrus branch canker in the southern California desert regions. Using morphological and molecular sequence data (ITS and $\beta$-tubulin), three distinct Eutypella spp., including E. citricola, E. microtheca, and an unidentified Eutypella sp., were identified from citrus branch samples showing cankers and dieback. These species have also been confirmed as pathogens of citrus because they were capable of producing lesions on citrus shoots. The unidentified Eutypella sp. is reported for the first time in citrus in California. $N$. hyalinum has been shown to be the predominate fungus found associated with citrus branch cankers in the southern California desert regions followed by E. citricola, E. microtheca, and the Eutypella sp.

The distribution of Eutypella spp. occurring on citrus has been reported from a number of regions, including Argentina, Australia, Brazil, China, Cote d'Ivore, Philippines, and the United States (California and Florida) (Adesemoye and Eskalen 2011; Anonymous 1960; Hanlin 1992; Rappaz 1987; Reinking 1918, 1921; Resplandy et al. 1954; Trouillas et al. 2011). In California, two Eutypella spp. were previously reported as associated with branch cankers of citrus in Riverside and San Diego Counties; however, these Eutypella spp. were not identified to species level (Adesemoye and Eskalen 2011). Three species of Eutypella in three citrus-growing counties in California were detected in the current study, including E. citricola, E. microtheca, and an unidentified Eutypella sp. These same Eutypella spp. are also associated with grapevine in the Coachella Valley (Trouillas et al. 2010) and E. citricola and E. microtheca have also been reported from citrus and grapevine in Australia (Trouillas et al. 2011). Eutypella spp. were the most frequently recovered fungi from grapevine cankers in the Coachella Valley (Trouillas et al. 2010), whereas $N$. hyalinum was the most frequently recovered canker pathogen of citrus in the current study. It is unknown how the occurrence of multiple susceptible hosts in a single area contributes to fungal distribution and prevalence in a particular host but it is clear that more work is needed to further evaluate these pathosystems to assess the potential risk imposed by plurivorous pathogens in areas with multiple hosts.

Identification of diatrypaceous fungi has largely been based on teleomorph morphology; however, in the absence of a sexual state, anamorph morphology provides very little in species delimitation because these asexual states often exhibit considerable morphological overlap (Glawe and Rogers 1984; Rappaz 1987). Studies using a multigene phylogenetic approach have successfully distinguished members of the Diatrypaceae family associated with various hosts, particularly in grapevine (Acero et al. 2004; Gramaje et al. 2012; Luque et al. 2012; Trouillas et al. 2011, 2010; Urbez-Torres et al. 2012). In this study, all three Eutypella spp. could be distinguished based on multigene phylogenetic analysis and this was further supported by differences in conidial and colony morphology. Little genetic variation was observed among isolates of E. citricola and no variation was seen for isolates of E. microtheca and the Eutypella sp. More robust methods of genetic analysis (e.g., amplified fragment length polymorphism, PCR fingerprinting, or microsatellite loci) may be necessary to detect intraspecific variation within these populations. To study intraspecific variation of Diplodia seriata De Not. occurring on grapevine, Elena et al. (2015) used the intersimplesequence repeat technique and determined two main groups of D. seriata; however, isolates obtained from different hosts or different geographic locations did not group into distinct clusters, suggesting a shared genetic background regardless of host or geographic origin. The use of such a technique can provide insight into the population

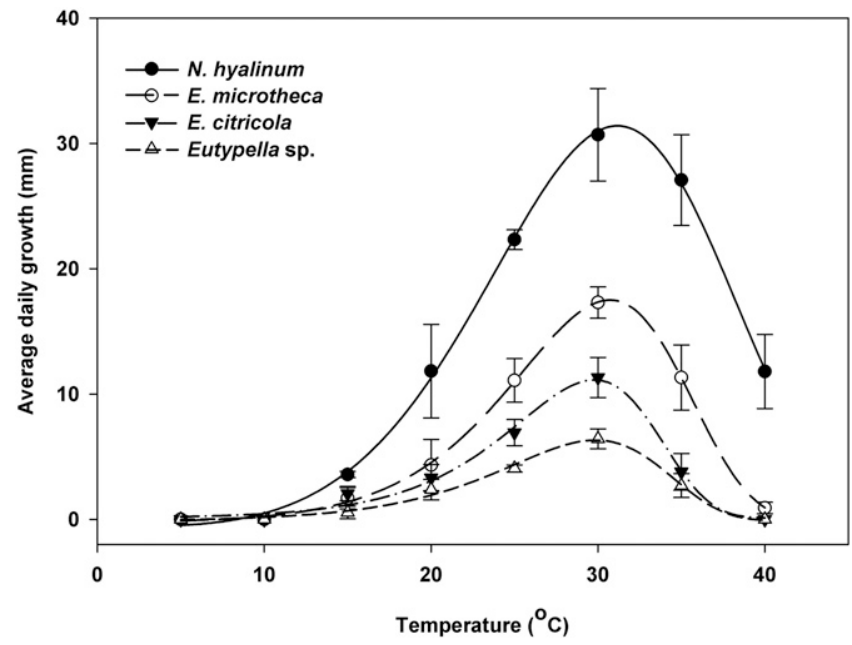

Fig. 2. Optimum temperature of Neoscytalidium hyalinum, Eutypella citricola, $E$ microtheca, and a Eutypella sp. Average daily growth (in millimeters) was derived from measurements at 2 and 3 days. Vertical bars represent standard errors of the mean.

Table 3. Percent (\%) recovery of Neoscytalidium hyalinum and Eutypella spp. in the southern California desert regions

\begin{tabular}{|c|c|c|c|c|c|c|c|c|}
\hline \multirow[b]{2}{*}{ County } & \multirow[b]{2}{*}{ Orchards $^{\mathbf{b}}$} & \multirow[b]{2}{*}{ Branch cankers ${ }^{\mathrm{c}}$} & \multicolumn{6}{|c|}{ Number $(\%)$ of branch cankers yielding ${ }^{a}$} \\
\hline & & & N. hyalinum (\%) & Eutypella spp. (\%) & Both $^{\text {d }}$ & Eutypella citricola & E. microtheca & Eutypella sp. \\
\hline Riverside & 4 & 144 & $55(38)$ & $20(14)$ & $1(1)$ & $11(55)$ & $6(30)$ & $3(15)$ \\
\hline Imperial & 4 & 99 & $27(27)$ & $16(16)$ & $2(2)$ & $9(56)$ & $5(31)$ & $2(13)$ \\
\hline San Diego & 1 & 30 & $3(10)$ & $8(27)$ & $1(3)$ & $6(75)$ & $0(0)$ & $2(25)$ \\
\hline Total number: & 9 & 273 & $85(31)$ & $44(16)$ & $4(1)$ & $26(59)$ & $11(25)$ & $7(16)$ \\
\hline
\end{tabular}

${ }^{a}$ Branch samples per county yielding indicated fungi.

${ }^{\mathrm{b}}$ Number of orchards surveyed by county.

c Number of branch cankers collected by county.

d Number of branch cankers yielding both $N$. hyalinum and a Eutypella spp.

Table 4. Conidial size of isolates from citrus branch canker used in this study and comparison with previous studies ${ }^{\mathrm{a}}$

\begin{tabular}{lccccc}
\hline & \multicolumn{2}{c}{ This study } & & Previous studies \\
\cline { 2 - 3 } Species & Conidial size $(\boldsymbol{\mu m})$ & Mean \pm SD $(\boldsymbol{\mu m})$ & & Conidial size $(\boldsymbol{\mu m})$ & Trouillas et al. 2010 \\
\hline Eutypella citricola & $(9)-14-19 \times(1)-1-2$ & $14.8 \pm 1.6 \times 1.1 \pm 0.1$ & & $10.5-16(-20) \times 1.5$ & Trouillas et al. 2011 \\
E. microtheca & $(8)-13-23 \times(1)-1-2$ & $14.1 \pm 2.4 \times 1.2 \pm 0.2$ & & $(14.00-) 17.63-18.82(-23.79) \times(1.33-) 1.45-1.52(-1.64)$ & Trouillas et al. 2010 \\
Eutypella sp. & $(12)-20-27 \times(1)-1-2$ & $20.2 \pm 2.0 \times 1.3 \pm 0.3$ & & $(17.5-) 20-25(-27.5) \times 1-1.5$ & S
\end{tabular}

${ }^{a}$ Conidial size, means, and standard deviation (SD) were determined from 30 conidia from at least five isolates from each species in the table. 
structure and diversity of Eutypella spp. occurring on citrus and grapevine in the southern California desert regions and can determine whether certain genotypes are host specific.

Concerning agricultural commodities in this area, it is unclear how transmission of these Eutypella spp. occurs between citrus and grapevine, which can be found growing in close proximity in the Coachella Valley. Perithecia (sexual fruiting bodies) of E. citricola and $E$. microtheca have been reported from both grapevine and citrus (Trouillas et al. 2010, 2011). Numerous perithecia were observed on dead, decaying citrus branches in the present study, suggesting that

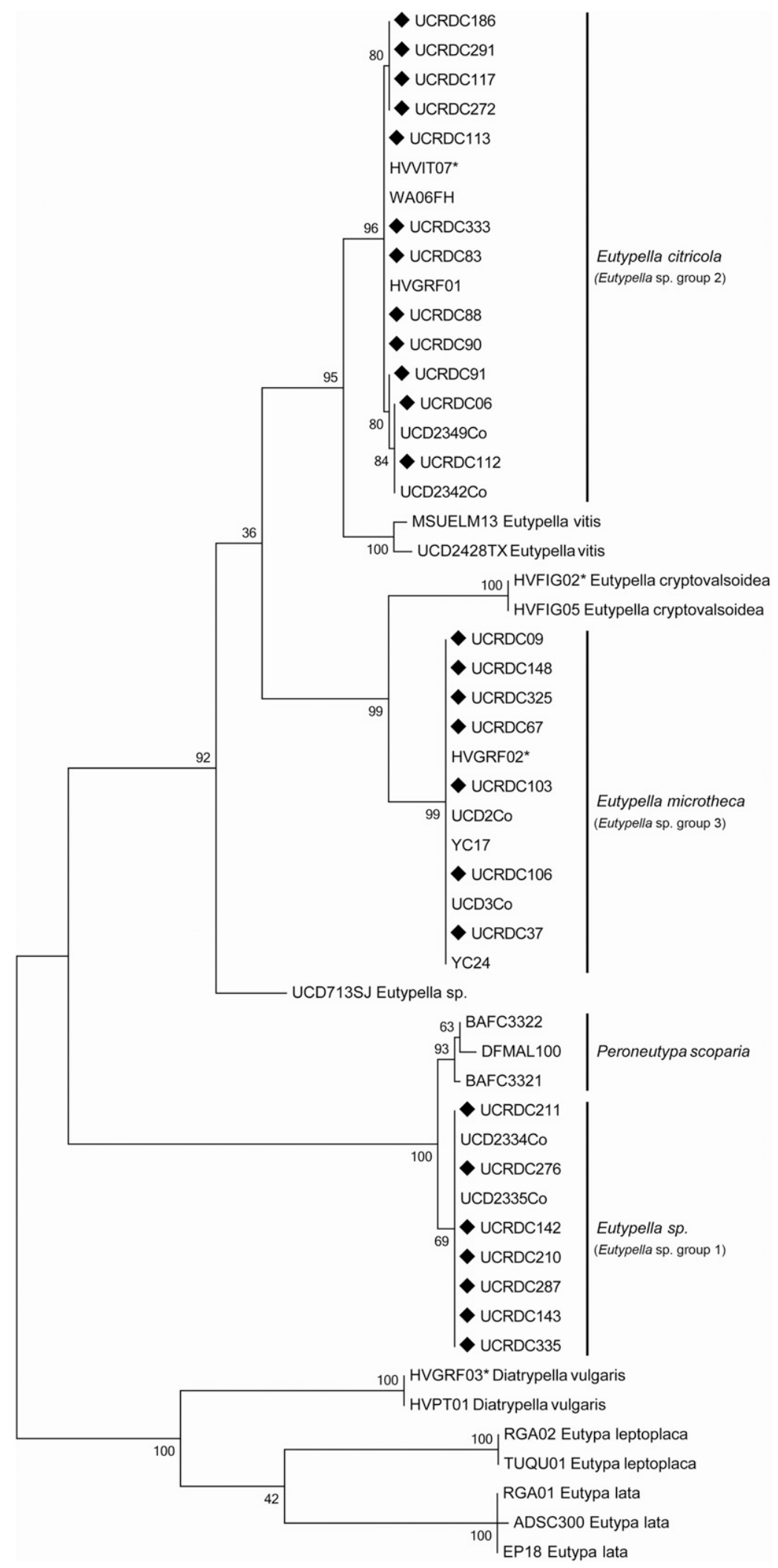

Fig. 3. One of the most-parsimonious unrooted trees based on internal transcribed spacer 1(ITS1), 5.8S ribosomal DNA, ITS2, and partial $\beta$-tubulin gene region sequences for isolates of species of the Diatrypaceae inferred from maximum-parsimony analysis. Numbers on branches are bootstrap values from 1,000 bootstrap replicates. Diamonds indicate isolates from this study and asterisks denote type-specimens. 
both citrus and grapevine are primary hosts for these pathogens because they are able to complete their life cycles. It is unclear at this time if other woody hosts (i.e., tamarisk) serve as primary hosts for these pathogens. Various studies have speculated on the factors contributing to fungal pathogen distribution, including the effects of temperature, physiological stresses, availability of hosts, and host overlap (Adesemoye et al. 2014; Leavitt 1990; Urbez-Torres 2011). It is essential that further studies be conducted to investigate the factors contributing to pathogen distribution and persistence by determining the effects among pathogen distribution and the relative abundance of primary hosts, cultural practices in use, and spore dispersal within and between hosts. This information is invaluable in understanding the seemingly complex epidemiology of these canker pathogens and will lead to better management strategies, particularly where there is host overlap in a region.

Several studies have proven pathogenicity of Eutypella spp. on their respective hosts, including E. parasitica, which causes Eutypella canker on Acer spp., and E. vitis and the Eutypella sp. on grapevine (Davidson and Lorenz 1938; French 1989; Trouillas 2009; UrbezTorres et al. 2009). Studies assessing E. vitis and the Eutypella sp. as pathogens on grapevine concluded that these species were capable of infecting host tissues, and recent work in Australia indicated that both E. citricola and E. microtheca were pathogenic on grapevine (Pitt et al. 2013; Trouillas 2009; Urbez-Torres et al. 2009). Two species of Eutypella were able to produce lesions on detached citrus shoots (Adesemoye and Eskalen 2011), corroborating results in the present study. The influence of temperature on lesion development suggests that, for E. microtheca, temperatures close to the optimal fungal growth temperature lead to larger lesions, suggesting enhanced disease development under permissive conditions (i.e., higher temperatures). The Eutypella sp. in the present study produced the largest lesions out of all fungi tested, in contrast to previous studies, where various Eutypella spp. were not the most virulent species in pathogenicity assays on grapevine (Pitt et al. 2013; Trouillas 2009; Urbez-Torres et al. 2009). This stresses the importance of this Eutypella sp. as a pathogen of citrus, and future studies should be aimed at further identifying and characterizing the virulence and host colonization of this species.

$N$. hyalinum is a well-known pathogen of desert citrus in California dating back to the 1950 s, when it was determined to be the cause

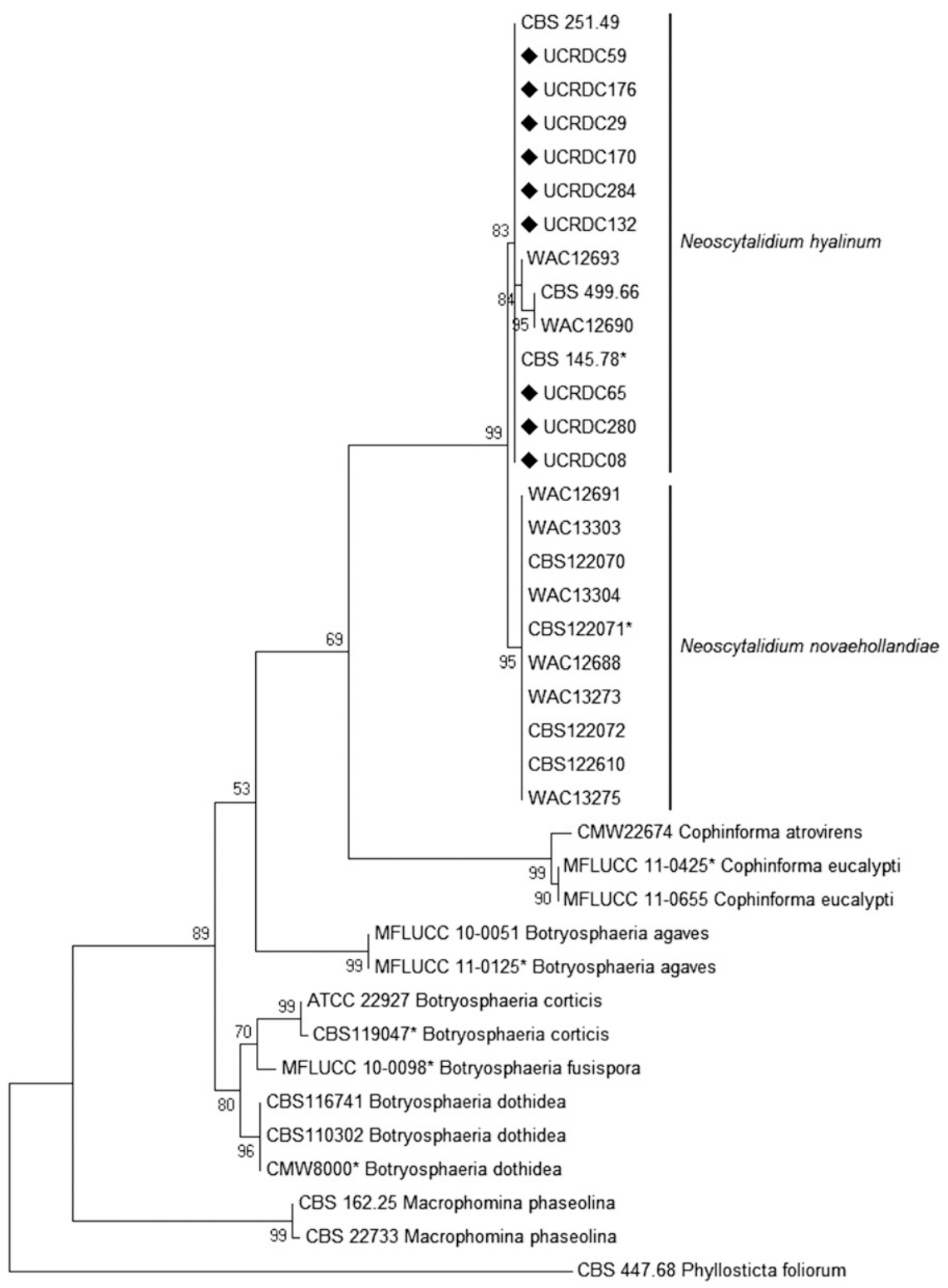

Fig. 4. One of the most-parsimonious unrooted trees based on internal transcribed spacer 1(ITS1), 5.8S ribosomal DNA, ITS2, and partial translation elongation factor 1- $\alpha$ gene region sequences for isolates of species of the Botryosphaeriaceae inferred from maximum-parsimony analysis. Numbers on branches are bootstrap values from 1,000 bootstrap replicates. Diamonds indicate isolates from this study and asterisks denote type specimens. CBS 447.68 (Phyllosticta foliorum) was added as an outgroup. 
of branch dieback and canker of grapefruit in southern California (Calavan and Wallace 1954). N. hyalinum is frequently observed in (semi)arid and tropical regions around the globe, where it can be found on apple, apricot, citrus, ficus, plum, pitahaya, and poplar (Chuang et al. 2012; Nattrass 1933, 1934; Oren et al. 2001; Polizzi et al. 2009; Ray et al. 2010, Sadowsky et al. 2007). It has also been reported from other woody hosts in California, including a Ficus sp., Juglans regia, and Prunus amygdalus (Chen et al. 2013; English et al. 1974; Inderbitzin et al. 2010). Regarding the effect of heat stress on disease development of Scytalidium wilt, Sadowsky et al. (2007) showed that a "very hot" $\left(34^{\circ} \mathrm{C}\right)$ temperature pre treatment was most conducive to infection with Scytalidium lignicola. The results of lesion development caused by $N$. hyalinum from the temperature study herein corroborates these results, suggesting that increased temperatures allow for more aggressive infection by this pathogen. Ten species of Botryosphaeriaceae associated with citrus branch canker were reported in California (Adesemoye et al. 2014); however, only two of these species were found associated with citrus in the desert regions; namely, N. hyalinum and Spencermartinsia viticola (A. J. L. Phillips \& J. Luque) A. J. L. Phillips, A. Alves \& Crous. During a survey of

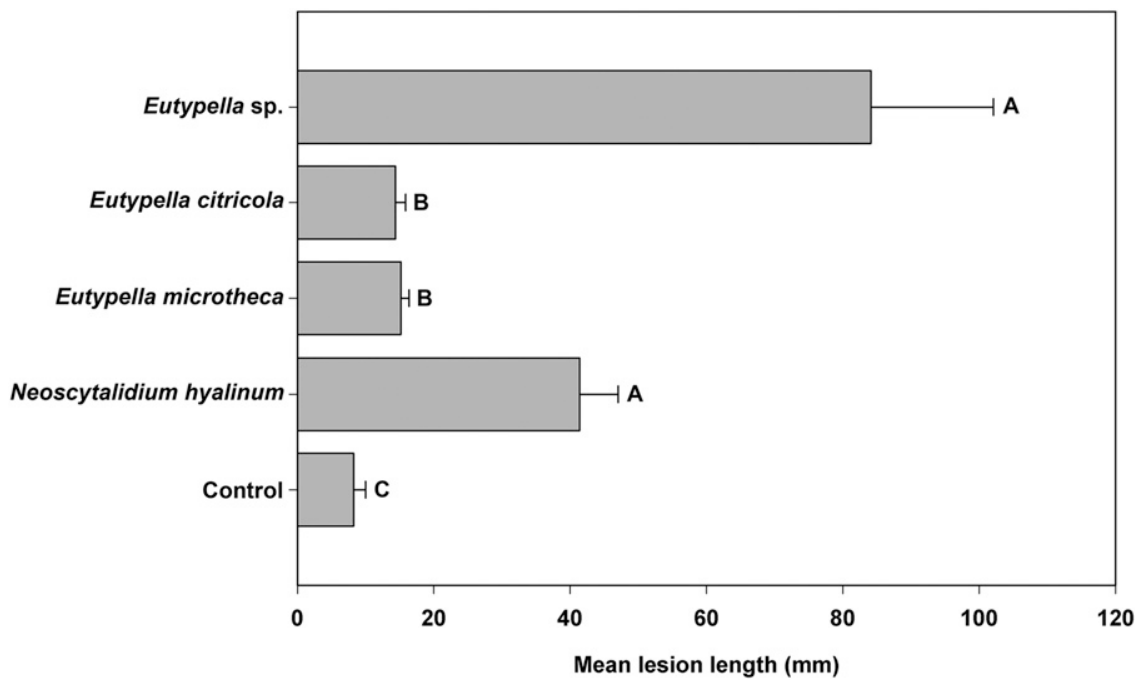

Fig. 5. Pathogenicity of Neoscytalidium hyalinum and Eutypella spp. on Lisbon lemon plants after 8 months. Horizontal lines represent standard error of the mean according to Tukey's honestly significant difference mean separation test at $\alpha=0.05$. Levels not connected by the same letter are significantly different.

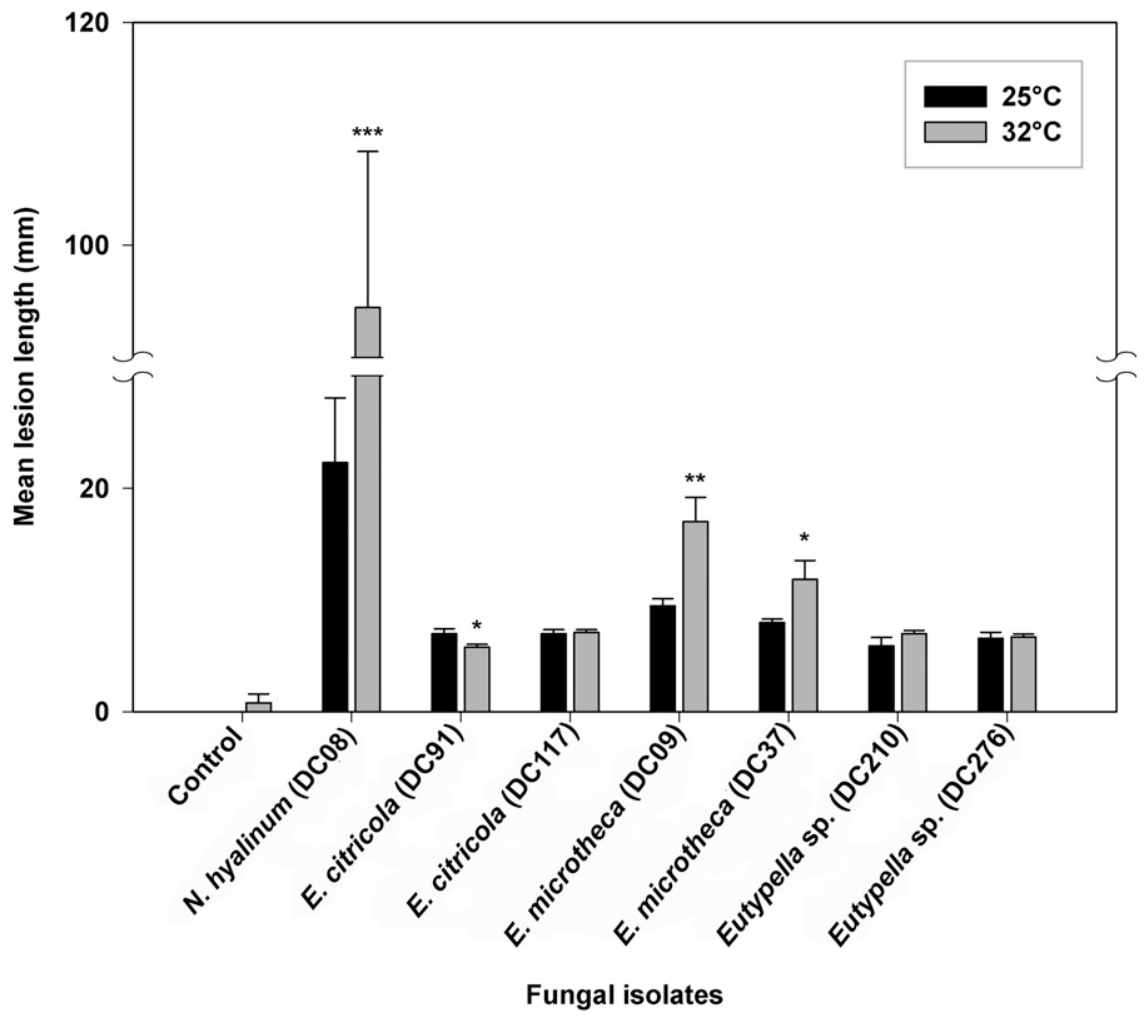

Fig. 6. Temperature study of Neoscytalidium hyalinum and Eutypella spp. on detached shoots of Lisbon lemon incubated at 25 or $32^{\circ} \mathrm{C}$. Vertical lines represent standard error of mean from an independent-samples $t$ test with confidence level $\alpha=0.05$. Asterisks indicate statistical significance $\left(^{*},{ }^{* *}\right.$, and ${ }^{* * *}=P<0.05,0.01$, and 0.001 , respectively) between temperature treatments within a fungal isolate. 
canker disease in California vineyards, Lasiodiplodia theobromae (Pat.) Griffon \& Maubl. was most abundant in vineyards in the Coachella Valley (Úrbez-Torres et al. 2006) and has been reported previously from citrus (French 1989). At present, it is unclear why other members of the Botryosphaeriaceae family previously reported on citrus were not detected during this survey but it is unlikely that any one factor such as temperature, host availability, geographic location, etc. can be responsible for fungal pathogen distribution; instead, a combination of these factors govern pathogen distribution (Adesemoye et al. 2014; Leavitt 1990; Urbez-Torres 2011). Expanded surveys of more groves may be necessary to determine whether other members of the Botryosphaeriaceae family are present. $N$. hyalinum was recently reported as a pathogen of grapevine from the Coachella Valley, citing an estimated $15 \%$ incidence of $N$. hyalinum of affected grapevines (Rolshausen et al. 2013), further supporting the need for continued research into the epidemiology of this pathogen as an important pathogen of agricultural commodities in the southern California desert regions.

Branch canker and dieback of citrus is an ongoing problem for citrus growers located in the desert areas of southern California. It is well known that physiological stresses can predispose trees to infection by canker pathogens and that injuries, including sunburn, frost damage, and mechanical damage, serve as points of entry for these pathogens (Calavan and Wallace 1954; Whiteside 1980). Management of branch canker is primarily achieved through various cultural practices, including but not limited to proper irrigation and fertilization, pruning during dry weather, removal of decaying or dead branches and twigs, and prompt disposal of infected material. Although cultural practices are the current management strategies recommended for citrus branch canker, areas with a high incidence of disease may benefit from the use of chemical control. Studies conducted in avocado and grapevine have shown a number of fungicides to be successful in inhibiting members of the Botryosphaeriaceae and Diatrypaceae families, respectively, and the use of these as pruning protectants has been studied (Gramaje et al. 2011; Pitt et al. 2012; Twizeyimana et al. 2013). In vitro studies and field trials are underway to determine the efficacy of various commercial products for use as pruning protectants on citrus against $N$. hyalinum and Eutypella spp.

\section{Acknowledgments}

We thank the California Citrus Research Board for providing funding for this research, the desert citrus growers for allowing us to survey their orchards, J. Barcinas (Pest Control Advisor) and G. Bender (University of California, Cooperative Extension Farm Advisor) for field assistance, S. C. Lynch for critical review of this manuscript, the anonymous reviewers for their helpful comments, and J. N. Rapicavoli for insightful scientific discussions during the course of this research.

\section{Literature Cited}

Acero, F. J., Gonzalez, V., Sanchez-Ballesteros, J., Rubio, V., Checa, J., Bills, G. F., Salazar, O., Platas, G., and Pelaez, F. 2004. Molecular phylogenetic studies on the Diatrypaceae based on rDNA-ITS sequences. Mycologia 96: 249-259.

Adesemoye, A. O., and Eskalen, A. 2011. First report of Eutypella spp. associated with branch canker of citrus in California. Plant Dis. 95:1187.

Adesemoye, A. O., Mayorquin, J. S., Wang, D. H., Twizeyimana, M., Lynch, S. C., and Eskalen, A. 2014. Identification of species of Botryosphaeriaceae causing Bot gummosis in citrus in California. Plant Dis. 98:55-61.

Anonymous. 1960. Index of Plant Diseases in the United States. U. S. Dep. Agric. Agric. Handb. 165. U. S. Department of Agriculture, Washington, DC.

Anonymous. 2009. Pest management strategic plan for citrus production in California. Online publication. California Citrus Quality Council, Auburn, CA. http://www.ipmcenters.org/pmsp/pdf/CACitrusPMSP.pdf

Anonymous. 2015. Citrus Fruits. Summary. Online publication. United States Department of Agriculture National Agricultural Statistics Service. http://usda. mannlib.cornell.edu/usda/nass/CitrFrui//2010s/2015/CitrFrui-09-17-2015.pdf

Calavan, E. C., and Wallace, J. M. 1954. Hendersonula toruloidea Nattrass on citrus in California. Phytopathology 44:635-639.

Carter, M. V. 1957. Eutypa armeniacae Hansf. \& Carter, sp. nov., an airborne vascular pathogen of Prunus armeniaca L. in southern Australia. Aust. J. Bot. 5:21-35.

Cenis, J. L. 1992. Rapid extraction of fungal DNA for PCR amplification. Nucleic Acids Res. 20:2380.

Chen, S. F., Fichtner, E., Morgan, D. P., and Michailides, T. J. 2013. First report of Lasiodiplodia citricola and Neoscytalidium hyalinum causing death of graft union of English walnut in California. Plant Dis. 97:993.
Chuang, M. F., Ni, H. F., Yang, H. R., Shu, S. L., Lai, S. Y., and Jiang, Y.-L. 2012. First report of stem canker disease of pitaya (Hylocereus undatus and Hylocereus polyrhizus) caused by Neoscytalidium dimidiatum in Taiwan. Plant Dis. 96:906.

Crous, P. W., Slippers, B., Wingfield, M. J., Rheeder, J., Marasas, W. F. O., Philips, A. J. L., Alves, A., Burgess, T., Barber, P., and Groenewald, J. Z. 2006. Phylogenetic lineages in the Botryosphaeriaceae. Stud. Mycol. 55: 235-253.

Davidson, R. W., and Lorenz, R. C. 1938. Species of Eutypella and Schizoxylon associated with cankers of maple. Phytopathology 28:733-745.

Elena, G., Garcia-Figueres, F., Reigada, S., and Luque, J. 2015. Intraspecific variation in Diplodia seriata isolates occurring on grapevines in Spain. Plant Pathol. 64:680-689.

English, H., Davis, J. R., and DeVay, J. E. 1974. Relationship of Botryosphaeria dothidea and Hendersonula toruloidea to a canker disease of almond. Phytopathology 65:114-122.

French, A. M. 1989. California Plant Disease Host Index. California Department of Food and Agriculture, Sacramento.

Glawe, D. A., and Rogers, J. D. 1984. Diatrypaceae in the Pacific Northwest. Mycotaxon 20:401-460.

Gramaje, D., Agustí-Brisach, C., Pérez-Sierra, A., Moralejo, E., Olmo, D., Mostert L., Damm, U., and Armengol, J. 2012. Fungal trunk pathogens associated with decay symptoms of almond trees in Mallorca (Spain). Persoonia 28:1-13.

Gramaje, D., Ayres, M. R., Trouillas, F. P., and Sosnowski, M. R. 2011. Efficacy of fungicides on mycelial growth of diatrypaceous fungi associated with grapevine trunk disease. Australas. Plant Pathol. 41:295-300.

Hanlin, R. T. 1992. Index to genera and species of ascomycetes described by A. P. Viegas. Mycotaxon 43:207-230.

Inderbitzin, P., Bostock, R. M., Trouillas, F. P., and Michailides, T. J. 2010. A six locus phylogeny reveals high species diversity in Botryosphaeriaceae from California almond. Mycologia 102:1350-1368.

Jacobs, K., Bergdahl, D. R., Wingfield, M. J., Halik, S., Seifert, K. A., Bright, D. E., and Wingfield, B. D. 2004. Leptographium wingfieldii introduced into North America and found associated with exotic Tomicus piniperda and native bark beetles. Mycol. Res. 108:411-418.

Leavitt, G. M. 1990. The occurrence, distribution, effect and control of Botryodiplodia theobromae on Vitis vinifera in California, Arizona, and northern Mexico. Ph.D. dissertation, University of California, Riverside.

Luque, J., Garcia-Figueres, F., Legorburu, F. J., Muruamendiaraz, A., Armengol, J., and Trouillas, F. P. 2012. Species of Diatrypaceae associated with grapevine trunk diseases in Eastern Spain. Phytopathol. Mediterr. 51:528-540.

McDonald, V., and Eskalen, A. 2011. Botryosphariaceae species associated with avocado branch cankers in California. Plant Dis. 95:1465-1473.

Miller, T. C., Gubler, W. D., Geng, S., and Rizzo, D. M. 2003. Effects of temperature and water vapor pressure on conidial germination and lesion expansion of Sphaerotheca macularis f. sp. fragariae. Plant Dis. 87:484-492.

Moller, W. J., and Kasimatis, A. N. 1978. Dieback of grapevine caused by Eutypa armeniacae. Plant Dis. Rep. 62:254-258.

Munkvold, G. P., and Marois, J. J. 1994. Eutypa dieback of sweet cherry and occurrence of Eutypa lata perithecia in the central valley of California. Plant Dis. 78:200-207.

Nattrass, R. M. 1933. A new species of Hendersonula (H. toruloidea) on deciduous trees in Egypt. Br. Mycol. Soc. Trans. 18:189-IN1-198-IN2.

Nattrass, R. M. 1934. Pages 48-57 in: Annual Report of the Mycologist for the Year 1933. Ann. Rep. Dep. Agric., Nicosia, Cyprus.

Oren, Y., Sadowsky, A., Gefen, D., Solel, Z., and Kimchy, M. 2001. Scytalidium wilt of citrus. Eur. J. Plant Pathol. 107:467-470.

Phillips, A. J. L., Alves, A., Abdollahzadeh, J., Slippers, B., Wingfield, M. J., Groenewald, J. Z., and Crous, P. W. 2013. The Botryosphaeriaceae: Genera and species known from culture. Stud. Mycol. 76:51-167.

Pitt, W. M., Sosnowski, M. R., Huang, R., Qiu, Y., Steel, C. C., and Savocchia, S. 2012. Evaluation of fungicides for the management of Botryosphaeria canker of grapevines. Plant Dis. 96:1303-1308.

Pitt, W. M., Trouillas, F. P., Gubler, W. D., Savocchia, S., and Sosnowski, M. R. 2013. Pathogenicity of diatrypaceous fungi on grapevines in Australia. Plant Dis. 97:749-756

Polizzi, G., Aiello, D., Vitale, A., Giuffrida, F., Groenewald, J. Z., and Crous, P. W. 2009. First report of shoot blight, canker, and gummosis caused by Neoscytalidium dimidiatum on citrus in Italy. Plant Dis. 93:1215.

Punithalingham, E. 1980. Plant diseases attributed to Botryodiplodia theobromae Pat. Bibl. Mycol. 71:21-26.

Rappaz, F. 1987. Taxonomie et nomenclature des Diatrypacées à asques octosporées. Mycol. Helv. 2:285-648.

Ray, J. D., Burgess, T., and Lanoiselet, V. M. 2010. First record of Neoscytalidium dimidiatum and $N$. novaehollandiae on Mangifera indica and $N$. dimidiatum on Ficus carica in Australia. Australas. Plant Dis. Notes 5:48-50.

Reinking, O. A. 1918. Philippine economic plant diseases. Philipp. J. Sci. 13: 165-274.

Reinking, O. A. 1921. Citrus diseases of the Philippines, southern China, IndoChina and Siam. Philipp. Agric. 9:121-179.

Resplandy, R., Chevaugeon, J., Delassus, M., and Luc, M. 1954. Premiere liste annotee de champignons parasites de plantes cultivees en Cote d'Ivoire. Ann. Epiphyt. 1:1-61. 
Rolshausen, P. E., Akgul, D. S., Perez, R., Eskalen, A., and Gispert, C. 2013. First report of wood canker caused by Neoscytalidium hyalinum on grapevine in California. Plant Dis. 97:1511.

Sadowsky, A., Solel, Z., and Sztejnberg, A. 2007. Effect of heat-stress predisposition on the development of Scytalidium wilt of 'Star Ruby' grapefruit, caused by Scytalidium lignicola. Eur. J. Plant Pathol. 117:123-127.

Siebert, J. B. 2001. Eutypa: The economic toll on vineyards. Wines Vines April: 50-56.

Slippers, B., Boissin, E., Phillips, A. J. L., Groenewald, J. Z., Lombard, L., Wingfield, M. J., Postma, A., Burgess, T., and Crous, P. W. 2013. Phylogenetic lineages in the Botryosphaeriales: A systematic and evolutionary framework. Stud. Mycol. 76:31-49.

Slippers, B., Crous, P. W., Denman, S., Coutinho, T. A., Wingfield, B. D., and Wingfield, M. J. 2004. Combined multiple gene genealogies and phenotypic characters differentiate several species previously identified as Botryosphaeria dothidea. Mycologia 96:83-101.

Tamura, K., Stecher, G., Peterson, D., Filipski, A., and Kumar, S. 2013. MEGA6: Molecular Evolutionary Genetics Analysis Version 6.0. Mol. Biol. Evol. 30: 2725-2729.

Thompson, J. D., Gibson, T. J., Plewniak, F., Jeanmougin, F., and Higgins, D. G. 1997. The CLUSTAL_X windows interface: Flexible strategies for multiple sequence alignment aided by quality analysis tools. Nucleic Acids Res. 25:4876-4882.

Trouillas, F. 2009. Taxonomy and biology of Eutypa and other Diatrypaceae species associated with grapevine canker diseases in California. Ph.D. dissertation, University of California, Davis.

Trouillas, F. P., Pitt, W. M., Sosnowski, M. R., Huang, R., Peduto, F., Loschiavo, A., Savocchia, S., Scott, E. S., and Gubler, W. D. 2011. Taxonomy and DNA phylogeny of Diatrypaceae associated with Vitis vinifera and other woody plants in Australia. Fungal Divers. 49:203-223.
Trouillas, F. P., Urbez-Torres, J. R., and Gubler, W. D. 2010. Diversity of Diatrypaceous fungi associated with grapevine canker diseases in California. Mycologia 102:319-336.

Twizeyimana, M., McDonald, V., Mayorquin, J. S., Wang, D. H., Na, F., Akgul, D. S., and Eskalen, A. 2013. Effect of fungicide application on the management of avocado branch canker (formerly Dothiorella canker) in California. Plant Dis. 97:897-902.

Urbez-Torres, J. R. 2011. The status of Botryosphaeriaceae species infecting grapevines. Phytopathol. Mediterr. 50 (Suppl.):S5-S45.

Urbez-Torres, J. R., Adams, P., Kama, J., and Gubler, W. D. 2009. Identification, incidence and pathogenicity of fungal species associated with grapevine dieback in Texas. Am. J. Enol. Vitic. 60:497-507.

Úrbez-Torres, J. R., Leavitt, G. M., Voegel, T., and Gubler, W. D. 2006 Identification and distribution of Botryosphaeria species associated with grapevine cankers in California. Plant Dis. 90:1490-1503.

Urbez-Torres, J. R., Peduto, F., Striegler, R. K., Urrea-Romero, K. E., Rupe, J. C., Cartwright, R. D., and Gubler, W. D. 2012. Characterization of fungal pathogens associated with grapevine trunk diseases in Arkansas and Missouri. Fungal Divers. 52:169-189.

van Niekerk, J. M., Crous, P. W., Groenewald, J. Z. (Ewald), Fourie, P. H., and Halleen, F. 2004. DNA phylogeny, morphology and pathogenicity of Botryosphaeria species on grapevines. Mycologia 96:781-798.

White, T. J., Bruns, T., Lee, S., and Taylor, J. 1990. Pages 315-322 in: PCR Protocols: A Guide to Methods and Applications. Academic Press, San Diego, CA.

Whiteside, J. O. 1980. Dothiorella Gummosis. Page 14 in: Compendium of Citrus Diseases, 1st ed. J. O. Whiteside, S. M. Garnsey, and L. W. Timmer, eds. American Phytopathological Society, St. Paul, MN. 